\title{
Exploring the Utility of Speech Intelligibility Rated by Parents for Screening Children with Speech Sound Disorders
}

\author{
Youngmee Lee \\ Department of Communication Disorders, Tongmyong University, Busan, Korea
}

Correspondence: Youngmee Lee, PhD Department of Communication Disorders, Tongmyong University, 428 Sinseon-ro, Nam-gu, Busan 48520, Korea

Tel: +82-51-629-2135

Fax: +82-51-629-2019

E-mail: ymlee3060@gmail.com

Received: September 5, 2017

Revised: December 30, 2017

Accepted: December 30, 2017

This research was supported by the Tongmyong University of Research Grants 2016 (No. 2016A005).
Objectives: It is important to find earlier measures for identify speech sound disorder (SSD) in the clinical setting. This study examined the relationships among chronological age, percentage of consonants correct $(\mathrm{PCC})$ and speech intelligibility rated by parents for each group, and investigated whether a speech intelligibility scale rated by parents can be a useful tool to distinguish children with SSD from children with typical speech development (TSD). Methods: A total of 78 children ( 55 children with TSD, 23 children with SSD) and their parents participated in this study. Parents rated their child's speech intelligibility with the intelligibility in context scale. A speech-language pathologist evaluated the children's speech production skills by using a standardized articulation test and analyzed the PCC of all children. Results: Speech intelligibility scores were significantly correlated with PCC in both groups (all $p s<.05$ ). In the logistic regression analysis, speech intelligibility rated by parents was a significant predictor for differentiating between the two groups $(\beta=-.350, p<$ .001). Conclusion: A speech intelligibility scale rated by parents can be a useful tool in differentiating between children with SSD and children with TSD.

Keywords: Speech sound disorder, Speech intelligibility, Screening
취학 전 아동은 만 4-5세에 의사소통에 필요한 말, 언어 기술을 습득하며, 나아가 글을 통한 의사소통(written communication) 능 력을 갖추기 위한 선수 기술을 학습한다(McLeod, 2013). 이 시기의 아동은 주변 사람들과 원활한 의사소통을 하면서, 말, 언어 발달뿐 만 아니라 사회, 정서, 인지도 적절하게 발달시켜나간다. 일부 아동 은 말소리장애(speech sound disorder)를 경험하며, 이들은 정상적 인 말 발달을 하는 아동에 비해 취학 전부터 청소년기에 이르기까지 또래 관계, 학업 성취, 직업 선택과 같은 일상생활 활동 참여에서 부 정적인 경험을 더 많이 하는 것으로 알려져 있다(Felsenfeld, Broen, \& McGue, 1994; McCormack, McLeod, McAllister, \& Harrison, 2009; McLeod, Harrison, McAllister, \& McCormack, 2013; Overby, Carrell, \& Bernthal, 2007). 말소리장애는 조음기관의 구조 및 생리적 결함(예: 청각장애, 뇌성마비 등), 음운 발달 문제, 원인을 명 확하게 알 수 없는 이유 등으로 말 산출에 문제가 있는 경우를 말한 다(Kim \& Shin, 2015). 취학 전 아동의 말소리장애 유병률(preva- lence)을 살펴보면, 2.3-24.6\%로, 말소리장애와 언어발달장애가 동 반된 경우는 4.5-19.0\%로 보고되고 있다(Kim, Ko, Seo, \& Oh, 2017; Law, Boyle, Harris, Harkness, \& Nye, 2000). 언어치료를 받고 있는 사례를 중심으로 살펴보면, 의사소통장애 아동의 29.1-44.1\%가 말 소리장애를 동반하는 것으로 보고되고 있다(Broomfield \& Dodd, 2004; Kim, Kim, Ha, \& Ha, 2015). 이처럼 높은 말소리장애 유병률 과 언어치료 참여 비율을 고려할 때, 말소리장애는 취학 전 아동에 게 흔하게 나타나는 발달장애 중의 하나로 간주될 수 있겠다.

언어치료사는 표준화된 발음평가를 실시하거나 자연스러운 상 황에서 연결발화(connected speech)를 수집하여 대상 아동의 자음 정확도(percentage of consonants correct, PCC), 음소목록(phonetic inventory), 음운변동(phonological process) 오류패턴 등을 분석하고, 규준(norm)이나 준거(criterion)와 비교하여 말소리장애 를 진단한다(Kim \& Shin, 2015; Law et al., 2000; Ng, To, \& McLeod, 2014). 말소리장애 아동의 언어치료 여부를 판단할 때는 말명료도 
(speech intelligibility)와 이해가능도(comprehensibility)가 결정적인 지표가 될 수 있기 때문에(Bernthal, Bankson, \& Flipsen, 2013), 언 어치료사는 대상 아동이 일상생활에서 다양한 대화상대자와 의 사소통할 때의 말명료도 및 이해가능도를 부모와의 면담을 통해 서 정보를 수집해야한다.

부모는 아동의 생애 초기부터 상호작용을 하는 주된 대화 상대 자이므로, 다양한 장소와 대화 상대자에 따른 아동의 의사소통 문 제를 가장 빨리 발견할 수 있다. McAllister, McCormack, McLeod 와 Harrison (2011)이 학령전기 아동의 부모( $\mathrm{N}=109)$ 를 대상으로 아동의 말소리 발달에 관한 설문 조사를 실시한 결과, 부모는 아동 이 교사, 가족, 친척, 부모의 지인 등과 같은 사람과 대화하는 상황 에서 아동의 말소리 발달 문제를 인식하며, 아동의 말소리 발달을 걱정하는 부모 중 일부는 언어치료 기관을 방문하여 아동의 말 산 출 능력에 대한 평가를 언어치료사에게 의뢰(referral)하는 것으로 나타났다. 하지만, 말소리장애 아동을 조기에 선별하는 정책과 시 스템 미비, 아동이 속한 지역 사회의 언어치료사수 부족, 장애 진단 에 대한 부모의 두려움 등이 작용된다면, 아동의 말소리장애의 조 기 진단과 언어치료가 늦어질 수 있겠다(McAllister et al., 2011). 국 내로 한정해서 살펴보면, 말소리장애 선별을 위한 다양한 선별도구 의 부족, 교사와 부모의 말소리장애에 대한 지식과 언어치료의 중 요성에 대한 인식 부족, 언어치료 비용에 대한 부담 등도 말소리장 애의 조기 선별과 언어치료 참여를 지연시킬 수 있다.

말소리장애도 다른 장애처럼 조기 선별과 언어치료 서비스의 제 공으로 아동의 말명료도를 향상시키고 교우 관계 및 학업 성취와 같은 잠재적인 문제를 예방하는 데 도움이 된다(Almost \& Rosenbaum, 1998; Broomfield \& Dodd, 2011). 명확한 원인 없이도 발생 되는 말소리장애 특성으로 인해 진단과 언어치료 제공이 조기에 이루어지기 어려운 측면을 고려할 때(McLeod, Press, \& Phelan, 2010), 언어치료의 효과가 높은 중요한 시기를 놓치지 않기 위한 대 안적인 방법을 찾는 것은 매우 중요하다. 대안적인 방법 중의 하나 가 부모 보고(parent report)를 통해 아동의 의사소통 행동을 평가 하여, 아동의 의사소통 발달 문제를 확인하는 것이다. 부모 보고는 생후 12 개월에서 30 개월 미만의 영유아의 말, 언어 발달을 평가하 는 데 유용한 것으로 알려져 있으며, 나아가 의사소통장애의 진단, 언어치료 목표 및 방향 설정에 필요한 신뢰로운 정보를 제공하기 때문에 임상 현장에서 광범위하게 활용되고 있다(Dale, 1991; Stertzbach, 2005). 최근에는 부모가 평가하는 아동의 말명료도검 사에 대한 관심이 높아지면서, 국외에서는 부모가 평가하는 아동 의 말소리 발달 및 말명료도검사의 신뢰도와타당도에 관한 연구가 활발히 진행되고 있다(Kim, Ballard, \& McCann, 2016; McLeod,
Harrison, \& McCormack, 2012a, 2012b; McLeod et al., 2013; Ng et al., 2014). Baudonck, Dhooge와 Van Lierde (2010)가 보청기 착용 아동, 인공와우 착용 아동, 일반 아동의 말명료도 평가를 부모와 언어치료사에게 실시한 결과, 부모가 언어치료사에 비해 아동의 말명료도를 높게 평가하는 경향은 있었지만 부모와 언어치료사간 의 말명료도 점수에 유의한 차이가 없는 것으로 나타났다. 이러한 결과는 아동의 발화에 대한 친숙도(familiarity)가 말명료도 평가 에 영향을 미치지만, 부모의 말명료도 평가 결과를 언어치료사의 평가만큼 신뢰할 수 있다는 것을 시사한다.

말소리장애 아동이 일상생활에서 경험할 수 있는 부정적인 영향 을 최소화하기 위해서 무엇보다 중요한 것은 말소리장애의 조기 선 별, 진단, 언어치료에 참여할 수 있도록 지원하는 것이다. 국내에는 말소리장애 아동을 조기에 선별할 수 있는 시스템이 부재하여, 부 모나 교사의 관찰로 말소리장애 아동의 진단과 언어치료가 의뢰되 기 때문에 진단과 언어치료가 늦어지고 있다. 이러한 상황에서 말 소리장애를 조기에 선별하여 언어치료사가 공식평가를 할 수 있도 록 하는 부모 보고 형태의 검사도구의 유용성을 탐색해보는 것은 의의가 있겠다. 현재 국내외에서 아동의 언어 발달을 평가하는 부 모 보고 형태의 검사는 광범위하게 사용되고 있지만, 부모가 평가 하는 아동의 말소리 발달에 관한 검사도구의 유용성과 필요성에 대한 연구는 미비한 상태이다. 이에 따라, 본 연구에서는 말소리장 애 아동과 일반 아동 집단에서 부모가 평정한 말명료도 점수가 아 동 연령과 표준화된 발음평가 결과인 자음정확도와 유의한 상관 을 보이는지 살펴보고자 하였다. 그리고 지역사회 기반의 교육현장 (예: 어린이집, 유치원 등)에서 부모가 평정하는 말명료도 척도가 절차 및 시간 측면에서 말소리장애 아동을 효율적으로 선별할 수 있는 유용한 임상적 도구가 될 수 있을지에 대해서 탐색하고자 하 였다.

이에 대한 본 연구의 구체적인 연구질문은 다음과 같다.

첫째, 집단(말소리장애 아동, 일반 아동) 각각에서 아동의 연령, 부모가 평정한 말명료도 점수, 언어치료사가 평가한 표준화된 발 음평가의 자음정확도 간에 유의한 상관을 보이는가?

둘째, 부모가 평정한 말명료도 점수가 말소리장애 아동과 일반 아동을 구분할수 있는 유의한 변수인가?

\section{연구방법}

\section{연구대상}

본 연구는 부산 지역에 거주하고 있는 만 4 세에서 6 세 사이의 말 소리장애 아동 $(\mathrm{N}=23)$ 과 일반 아동 $(\mathrm{N}=55)$, 총 78 명의 아동과 어 
Youngmee Lee - Speech Intelligibility of Children with SSD as Judged by Their Parents

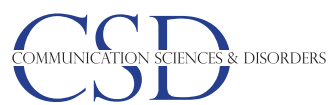

머니를 대상으로 하였다.

본 연구에 참여한 말소리장애 아동은 (1) 부모 및 교육기관의 담 임교사에 의해 말소리 발달에 문제가 있다고 보고되거나 검사당시 3 개월 이내에 언어치료사에 의해 말소리장애로 진단되었으며, (2) 아동용 발음평가(Assessment of Phonology and Articulation for Children, APAC; Kim, Pae, \& Park, 2007)에서 자음정확도가 생활 연령을 기준으로 -2 표준편차 이하에 속하며, (3) 수용 및 표현어휘 력검사(Receptive and Expressive Vocabulary Test, REVT; Kim, Hong, Kim, Jang, \& Lee, 2009)의 수용어휘력 점수에서 생활연령 을 기준으로 정상 범주(-1 표준편차 이상)에 속하며, (4) 중복장애 (예: 자폐스펙트럼장애, 청각장애, 지적장애 등) 진단을 받지 않은 아동만을 대상으로 선정하였다. 일반 아동은 (1) 부모 및 교육기관 의 담임교사의 보고에 의해 인지, 언어, 신체 발달이 정상적이며, (2) 아동용 발음평가(APAC; Kim et al., 2007)에서 생활연령을 기준으 로 자음정확도가 정상 범주(-1 표준편차 이상)에 속하며, (3) 수용 및 표현어휘력검사(REVT; Kim et al., 2009)의 수용어휘력 점수에 서 생활연령을 기준으로 정상 범주에 속하며, (4) 사회, 정서, 행동 상에 문제가 없는 아동만으로 선정하였다.

두 집단의 성별을 살펴보면, 말소리장애 아동 집단은 남아 13 명, 여아 10 명이었으며, 일반 아동 집단은 남아 27 명, 여아 28 명이었다. 평균 생활연령을 살펴보면, 말소리장애 아동은 64.6 개월 $(\mathrm{SD}=8.8)$, 일반 아동은 65.2 개월 $(\mathrm{SD}=9.3)$ 이었다. 말소리장애 아동의 평균 자 음정확도는 $78.1 \%(\mathrm{SD}=19.8)$, 일반 아동의 평균 자음정확도는 98.7\% (SD = 2.5)였다. 수용어휘의 평균 점수는 말소리장애 아동은 49.3점(SD=13.3), 일반 아동은 56.4점(SD=12.1)이었다. 말명료도 를 평정한 주양육자의 평균 연령을 살펴보면, 말소리장애 아동의 주양육자는 39.8 세 $(\mathrm{SD}=6.8)$, 일반 아동의 주양육자는 37.9 세(SD =6.9)였다. 집단 간의 통제가 잘 이루어졌는지를 확인하기 위하여 독립표본 $t$-검정을 실시한 결과, 생활연령 $(t(76)=.278, p>.05)$ 과 수 용어휘 점수 $(t(76)=.419, p>.05)$ 에서는 집단 간에 유의한 차이가 없으나, 자음정확도 $(t(76)=7.643, p<.001)$ 에서는 집단 간에 유의 한 차이가 있었다. 두 집단 아동의 생활연령, 수용어휘 점수, 자음 정확도의 평균, 표준편차, 범위는 Table 1에 제시하였다.

\section{연구도구}

본 연구에서는 대상 아동의 자음정확도를 산출하기 위해서 아동 용 발음평가(APAC; Kim et al., 2007)를 사용하였으며, 부모가 평 정하는 말명료도를 산출하기 위해서 특정 대화자 말명료도 척도한국어판(Intelligibility in Context Scale-Korea version; McLeod et al., 2012a)을 사용하였다.
Table 1. Participants' characteristics

\begin{tabular}{lcc}
\hline & $\operatorname{SSD}(\mathrm{N}=23)$ & $\operatorname{TSD}(\mathrm{N}=55)$ \\
\hline Sex & & \\
Male & 13 & 27 \\
Female & 10 & 28 \\
Age $(\mathrm{mo})$ & $64.6 \pm 8.8(53-80)$ & $65.2 \pm 9.3(48-81)$ \\
PCC $\left.^{\mathrm{a}} \%\right)$ & $78.1 \pm 19.8(24.3-95.7)$ & $98.7 \pm 2.5(90.0-100.0)$ \\
REVT-R $^{\mathrm{b}}$ & $49.3 \pm 13.3(16-60)$ & $56.4 \pm 12.1(28-87)$ \\
\hline
\end{tabular}

Values are presented as mean $\pm \mathrm{SD}$ (range).

$S S D=$ children with speech sound disorder; $T S D=$ children with typical speech development; $\mathrm{PCC}=$ percentage of consonants correct.

${ }^{a}$ Assessment of Phonology and Articulation for Children (Kim, Pae, \& Park, 2007).

${ }^{b}$ Receptive \& Expressive Vocabulary Test (Kim, Hong, Kim, Jang, \& Lee, 2010).

\section{아동용 발음평가}

본 연구에서는 아동의 자음정확도 측정을 위해서 표준화된 발 음평가 도구(APAC; Kim et al., 2007)를 사용하였다. 해당 검사는 어린 연령의 아동에게 친숙도가 높은 37 개의 단어로 구성되어 있 으며, 단어의 음절길이가 1-4음절의 명사, 동사, 형용사로 이루어져 있다. 음성학적 균형(phonetic balancing)을 고려하여 70개의 목표 자음이 단어 내 어두초성, 어중종성, 어중초성, 어말종성에 배치되 어 있으며, 자음정확도 산출을 통해서 아동의 말소리발달장애 유 무를 진단할 수 있도록 취학 전 아동의 연령별 규준(norm)이 갖추 어져 있다.

\section{특정 대화자 말명료도 척도(한국어판)}

본 연구에서는 부모가 평정하는 아동의 말명료도를 측정하기 위 해서 특정 대화자 말명료도 척도-한국어판(McLeod et al., 2012a) 을 사용하였다. 이 척도는 이중언어 언어치료사 및 언어학자에 의 해서 60 개 이상의 언어(예: 한국어, 일본어, 중국어 등)로 번안되어 다양한 언어와 문화권의 연구자에 의해서 타당도 및 신뢰도 연구 가 진행되고 있다(http://www.csu.edu.au/research/multilingualspeech/ics). 그리고 McLeod, Crowe와 Shahaeian (2015)은 호주에 서 영어를 사용하는 4 세에서 5 세 5 개월의 아동을 대상으로 특정 대화자 말명료도 척도에 대한 타당도 연구를 실시하여 높은 수준 의 타당도 및 신뢰도를 보고하였다. 해당 척도는 부모가 다양한 대 화 상대자(부모, 직계가족, 친척, 또래 친구, 교사, 아는 사람, 낯선 사람)가 자녀의 말을 이해하는 정도를 관찰하여 평정하도록 개발 되었다. 해당 검사는 총 7 개의 문항으로 구성되어 있으며, 부모의 평정에 따라서 총점과 평균 점수로 말명료도 점수를 산출하도록 되어 있다(Table 2). 부모는 한 달 동안의 아동의 말명료도를 5점 척 도 $(5$ 점 $=$ 항상, 4 점 $=$ 자주, 3 점 $=$ 가끔, 2 점 $=$ 드물게, 1 점 $=$ 전혀 못 함)로 평가하며, 검사의 소요시간은 약 5 분 정도이다(Appendix 1). 
Table 2. Intelligibility in context scale

\begin{tabular}{|c|c|c|c|c|c|}
\hline Item & Always & Usually & Sometimes & Rarely & Never \\
\hline 1. Do you understand your child? & 5 & 4 & 3 & 2 & 1 \\
\hline 2. Do immediate members of your family understand your child? & 5 & 4 & 3 & 2 & 1 \\
\hline 3. Do extended members of your family understand your child? & 5 & 4 & 3 & 2 & 1 \\
\hline 4. Do your child's friends understand your child? & 5 & 4 & 3 & 2 & 1 \\
\hline 5. Do other acquaintances understand your child? & 5 & 4 & 3 & 2 & 1 \\
\hline 6. Do your child's teachers understand your child? & 5 & 4 & 3 & 2 & 1 \\
\hline 7. Do strangers understand your child? & 5 & 4 & 3 & 2 & 1 \\
\hline Total score $=$ & & & & & \\
\hline Average total score $=\quad / 5$ & & & & & \\
\hline
\end{tabular}

From http://www.csu.edu.au/research/multilingual-speech/ics.

\section{연구절차}

본 연구에서는 부산 지역의 언어치료실, 복지관, 병원, 어린이집, 유치원에 연구 협조문을 팩스로 발송한 후, 해당 기관의 담당자에 게 유선으로 연구 목적, 내용, 협조 사항에 대해서 설명하였다. 연 구자는 연구 협조를 약속한 총 15 곳을 방문하여, 기관 담당자에게 아동의 법적 보호자인 부모에게 제공할 연구 안내문을 제공하였 다. 이때, 연구자는 연구 안내문을 숙지하고 연구 참여에 동의한 대상자에 한해서, 아동에게는 발음평가를 실시하였고 부모에게 는 말명료도 평정척도를 제공하였다. 말명료도 부모 평정지는 기 관장의 도움을 받아서 직접 혹은 가정통신문의 형태로 수거하였 으며, 가정통신문으로 발송된 말명료도 부모 평정지는 $97.5 \%$ 수거 되었다.

\section{자료 처리 및 신뢰도}

본 연구에서는 자음정확도는 아동용 발음평가(APAPC)를 통해 0-100\%로 산출하였으며, 부모가 평정하는 말명료도는 특정 대화자 말명료도 척도의 총점 산출 기준에 따라 0-35점으로 산출하였다.

자음정확도 채점에 대한 평가자 간 신뢰도(inter-rater reliability) 를 구하기 위해서, 연구자 외에 언어병리학 석사 수료생 1 명이 제 2 평가자로 참여하였다. 연구자는 자음정확도 산출에 대한 기준을 제 2 평가자에게 설명하였으며, 전체 자료의 $15 \%$ 에 해당하는 자료를 무작위로 추출하여 개별적으로 점수를 산출하였다. 신뢰도는 연구 자와 제 2 평가자의 자음정확도가 일치하는지에 대해서 살펴보았으 며, 그 결과, 평가자 간 신뢰도는 $96 \%$ 로 나타났다.

\section{통계분석}

본 연구에서 수집된 자료는 IBM SPSS Statistics version 23 (IBM Co., Armonk, NY, USA)을 이용하여 분석하였다. 집단 간 비교를 위해 정규성 검정(normality test)을 실시하기 위해서 Kolmogorov-
Smirnov 검정을 적용한 결과, 일반 아동 집단의 부모 평정 말명료 도와 자음정확도가 정규성 가정에 위배되는 것으로 나타났다. 이 에 따라, 말소리장애 아동과 일반 아동 간에 부모가 평정한 말명료 도에 유의한 차이가 있는지 알아보기 위해서 비모수 통계 방법인 Mann-Whitney U-검정을 실시하였다. 그리고 두 집단 각각에서 아 동의 연령, 부모 평정 말명료도, 자음정확도 간의 상관관계를 알아 보기 위해서 Pearson의 적률상관계수(Pearson product monument correlation)를 산출하였다. 또한, 부모가 평정한 말명료도 점수가 말소리장애 아동과 일반 아동을 구분하는 데 유의한 변수인지 알 아보기 위해서 이항 로지스틱 회귀분석(binary logistic regression) 을 실시하였다.

\section{연구결과}

\section{부모 평정 말명료도 점수에 대한 기술통계}

말소리장애 아동과 일반 아동의 부모가 평정한 말명료도 점수를 살펴보면, 말소리장애 아동은 27.7 점 $(\mathrm{SD}=3.9)$, 일반 아동은 32.4 점 $(\mathrm{SD}=3.2)$ 이었다. 이러한 점수 차이가 통계적으로 유의한지 살펴보 기 위해서 Mann-Whitney $U$-검정을 실시한 결과, 집단 간의 부모 평정 말명료도 점수에 유의한 차이가 있었다 $(Z=-4.510, p<.001)$.

\section{각 집단에서 아동의 연령, 부모 평정 말명료도 점수, 자음정확도 간 상관관계}

집단 각각에서 아동의 연령, 부모 평정 말명료도 점수, 자음정확 도 간의 상관관계를 살펴보기 위해서 Pearson의 적률상관분석을 실시하였다. 그 결과, 부모 평정 말명료도 점수와 자음정확도 간의 상관관계가 말소리장애 아동 $(r=.673, p<.001)$ 과 일반 아동 $(r=.299$, $p<.05$ ) 집단 모두에서 유의하였다(Figure 1, Tables 3, 4). 

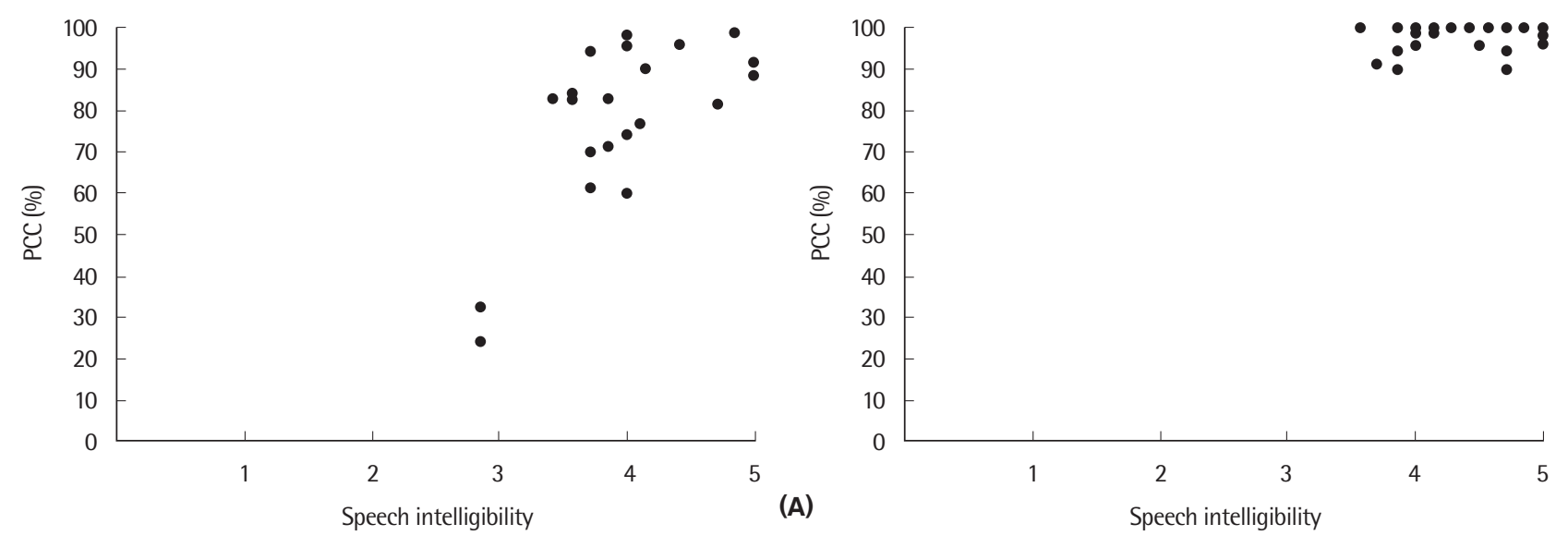

(B)

Figure 1. Scatterplot of the percentage of consonants correct and speech intelligibility for children with speech sound disorders and children with typical speech development. (A) PCC and SI for children with SSD. (B) PCC and SI for children with TSD.

$\mathrm{PCC}=$ percentage of consonants correct; $\mathrm{SI}=$ speech intelligibility; $S S D=$ speech sound disorder; $T S D=$ typical speech development.

Table 3. Correlation coefficients among factors in children with speech sound disorders ( $\mathrm{N}=23)$

\begin{tabular}{lcc}
\hline & Age & $\mathrm{Sl}^{\mathrm{a}}$ \\
\hline Age & - & - \\
$\mathrm{Sl}^{\mathrm{a}}$ & .272 & - \\
$\mathrm{PCC}^{\mathrm{b}}$ & .270 & $.673^{* * *}$ \\
\hline
\end{tabular}

$\mathrm{SI}=$ speech intelligibility; $\mathrm{PCC}=$ percentage of consonants correct.

${ }^{a}$ Assessment of Intelligibility in Context Scale-Korean version (McLeod, Harrison, \& McCormack, 2012a).

${ }^{b}$ Assessment of Phonology and Articulation for Children (Kim, Pae, \& Park, 2007). ${ }^{* * *} p<.001$.

\section{부모 평정 말명료도 점수와 말소리장애 진단과의 관련성}

부모가 평정한 말명료도 점수가 말소리장애 아동과 일반 아동 을 구분하는 데 유의한 변수인지를 확인하기 위해서 이항 로지스 틱 회귀분석(binary logistic regression)을 실시하였다. 종속변수는 집단(말소리장애 아동, 일반 아동)이며, 말소리장애 아동을 1 , 일반 아동을 0 으로 입력하였다. 부모 평정 말명료도 점수를 로지스틱 회 귀분석 모델에서 집단(말소리장애 아동, 일반아동)을 구분하는 독 립변수로 입력하였다. 로지스틱 회귀분석을 실시한 결과, 회귀분석 모델은 통계적으로 유의하였으며 $\left(\chi^{2}(1)=23.370, p<.001\right)$, 부모 평 정 말명료도 점수가 말소리장애 아동의 진단과 관련성이 높았다 (Wald's $\chi^{2}(1)=16.134, p<.001$, odds ratio=.705). 즉, 부모 평정 말 명료도 점수가 낮을수록 말소리장애 아동으로 분류되었으며 $(\beta=$ $-.350, p<.001$ ), 분류 정확도는 $78.2 \%$ 로 나타났다(Table 5).

\section{논의 및 결론}

본 연구에서는 말소리장애 아동과 일반 아동 집단에서 부모 평
Table 4. Correlation coefficients among factors in children with typical speech development $(\mathrm{N}=55)$

\begin{tabular}{lcc}
\hline & Age & $\mathrm{Sl}^{\mathrm{a}}$ \\
\hline Age & - & \\
$\mathrm{Sl}^{\mathrm{a}}$ & .014 & - \\
$\mathrm{PCC}^{\mathrm{b}}$ & $.316^{*}$ & $.299^{*}$ \\
\hline
\end{tabular}

$\mathrm{SI}=$ speech intelligibility; $\mathrm{PCC}=$ percentage of consonants correct.

${ }^{a}$ Assessment of Intelligibility in Context Scale-Korean version (McLeod, Harrison, \& McCormack, 2012a).

${ }^{\mathrm{b}}$ Assessment of Phonology and Articulation for Children (Kim, Pae, \& Park, 2007). ${ }^{*} p<.05$.

Table 5. Logistic regression analysis of SI rated by parents associated with children with speech sound disorder

\begin{tabular}{cccccc}
\hline & $\beta$ & SE & Wald's $\chi^{2}$ & $p$-value & OR \\
\hline $\mathrm{Sl}^{\mathrm{a}}$ & -.350 & .087 & 16.134 & .000 & .705 \\
\hline
\end{tabular}

$\mathrm{SI}=$ speech intelligibility; $\beta$ = regression coefficient; $\mathrm{SE}=$ standard error of the mean; $\mathrm{OR}=$ odds ratio.

${ }^{a}$ Assessment of Intelligibility in Context Scale-Korean version (McLeod, Harrison, \& McCormack, 2012a).

정 말명료도 점수가 아동의 연령, 표준화된 발음평가의 자음정확 도 간에 유의한 상관이 있는지를 살펴보았다. 그리고 부모가 평정 한 말명료도 점수가 말소리장애 아동과 일반 아동을 분류하는 데 유의한 변수인지를 로지스틱 회귀분석을 통해 살펴봄으로써, 부모 평정 말명료도 척도가 말소리장애 아동의 선별에 유용하게 활용될 수 있는지에 대해서 살펴보고자 하였다.

본 연구에서 말소리장애 아동과 일반 아동 집단 각각에서 부모 평정 말명료도 점수가 아동의 연령과 표준화된 발음평가의 자음정 확도와 유의한 상관을 보이는지 확인한 결과, 두 집단 모두에서 부 
모 평정 말명료도 점수와 자음정확도 간에 유의한 상관을 보였다. 즉, 부모가 일상생활에서 다양한 대화 상대자에 따른 아동의 말명 료도를 관찰하여 평가한 결과가 언어치료사가 표준화된 발음평가 로 평가한 결과와 상관이 높게 나타난 것이다. 이는 부모 보고 프로 토콜이 취학 전 아동의 말, 언어 발달을 평가하는 데에도 유용하게 활용될 수 있다는 선행연구(Dale, 1991; Kim et al., 2016; McLeod et al., 2012b; Stertzbach, 2005)의 결과를 지지한다고 할 수 있다. McLeod 등(2012b)의 연구에서는 부모 평정 말명료도 점수와자음 정확도 간에 유의한 상관을 보였으며, 이에 대해 저자들은 부모 평 정 말명료도 척도가 기능적인 말명료도를 평가하는 새로운 도구로 사용될 수 있음을 강조하였다. Kim 등(2016)은 부모 평정 말명료 도 척도가 이중언어 아동의 말소리장애를 선별하는 도구로 역할을 할 수 있는지 살펴보기 위해서, 한국어와 영어 각각에 대한 표준화 된 발음평가를 아동에게 실시하고 부모에게는 두 언어 각각에 대 한 부모 평정 말명료도 평가를 실시하였다. 그 결과, 두 언어 모두에 서 부모 평정 말명료도 점수와 표준화된 발음평가의 자음정확도 간에 유의한 상관을 보였다. 이러한 결과는 부모 평정을 통한 아동 의 말명료도 척도가 아동이 사용하는 언어에 무관하게 말소리장 애 아동의 조기 선별에 활용될 수 있다는 것을 시사한다.

본 연구에서는 말소리장애 아동의 부모 평정 말명료도가 일반 아동에 비해서 유의하게 낮았으며, 이는 말소리장애 아동의 말명 료도가 일반 아동에 비해서 낮다고 보고한 선행연구(Baudonck et al., 2010; Hustad, Schueler, Schultz, \& DuHadway, 2012) 결과와 일 치한다. Hustad 등(2012)은 취학 전의 뇌성마비 아동과 일반 아동 의 발화를 부모와 일반 청자에게 들려주고 받아쓰기와 평정척도 방법으로 말명료도를 평가하도록 하였다. 그 결과, 뇌성마비 아동 의 말명료도가 일반 아동에 비해 유의하게 낮았으며, 부모와 일반 청자의 말명료도 점수 간에 유의한 차이가 없었다. Baudonck 등 (2010)이 인공와우 착용 아동, 보청기 착용 아동, 일반 아동의 발화 를 수집하여 부모와 언어치료사에게 발화를 들려주고 평정척도로 말명료도를 측정한 결과에서도 인공와우 아동과 보청기 착용 아 동의 말명료도가 일반 아동에 비해서 유의하게 낮았다. 이러한 결 과는 말소리장애의 원인, 말명료도 평가 방법 및 근거 자료, 평가자 등에 상관없이 말소리장애 아동의 말명료도가 일반 아동에 비해 서 낮다는 것을 의미한다.

부모 평정 말명료도 점수는 취학 전 아동의 말소리장애 진단과 관련성이 높은 유의한 변수였다. 이러한 결과는 본 연구에서 사용 한 부모 평정 말명료도 척도의 특성과 관련이 있을 것으로 생각된 다. 부모가 취학 전 일반 아동이나 말소리장애 아동의 말명료도를 측정한 선행연구(Baudonck, Buekers, Gillebert, \& Van Lierde,
2009; Baudonck et al., 2010; Flipsen, 1995; Hustad et al., 2012; Kim $\& \mathrm{Ha}, 2012)$ 를 살펴보면, 주로 낱말 확인 과제나 평정척도를 이용 하여 부모 본인이 인식하는 아동의 말명료도를 평가하는 방법을 사용하였다. 즉, 아동이 일상생활에서 경험하는 다양한 대화상대 자들이 아동의 발화에 어떻게 반응하는지에 대한 정보는 포함하 지 않은 채, 아동의 발화에 대한 부모의 인식에만 기반하여 말명료 도 평가가 진행된 것으로 아동의 생태환경적 맥락을 고려한 평가로 보기는 어렵다. 본 연구에서 사용한 말명료도 척도는 세계보건기 구(World Health Organization)가 개발한 국제기능-장애·건강분 류의 아동 청소년 버전인 ICF-CY (International Classification of Functioning, Disability and Health: Children and Youth Version) 을 토대로 환경적인 맥락을 고려하여 개발되어진 것으로, 부모가 본인을 포함한 다양한 대화상대자(예: 친척, 교사, 친구, 낮선 사람 등)가 아동의 발화에 대한 반응과 인식을 부모가 관찰하여 평정하 도록 되어 있다. Stertzbach (2005)는 아동의 말명료도에 대한 부모 의 지인(예: 친구, 이웃 등), 친척, 낯선 사람들의 인식과 의견이 말소 리장애를 선별하는 데 중요한 변수로 작용한다고 언급하였다. McAllister 등(2011)도 상당수의 부모들이 주변 지인들과 아동이 대화하는 상황에서 아동의 말소리 발달 문제를 인식하는 경향이 있다는 것을 강조한 바 있다. 즉, 청자의 친숙도 효과로 인하여 부모 본인이 인식하는 아동의 말명료도는 과대평가될 수도 있으므로, 말소리장애 아동의 선별에는 부모를 포함한 타인의 의견과 생각이 반영된 부모 보고 형태의 말명료도 정보가 신뢰롭고 타당한 대안 적 방법으로 활용될 수 있을 것이다.

본 연구를 통해서 부모 평정 말명료도 척도가 말소리장애를 선 별하는 데 임상적으로 유용한 검사 도구로 활용될 수 있는 가능성 을 지니고 있다는 것을 확인하였다. 부모 평정 말명료도 척도는 말 소리 발달에 문제가 있거나 의심되는 아동을 빨리 선별하여 언어 치료사에게 적절한 진단과 언어치료를 받도록 하는 데 도움을 줄 수 있을 것으로 생각된다. 현재 국내에서는 취학 전 교육기관에 재 학 중인 의사소통장애 아동을 선별하는 시스템이 부재한 상황을 고려할 때, 부모 평정 말명료도 척도가 말소리장애 아동의 선별에 유용하게 이용되어 말소리장애 아동이 겪을 수 있는 문제를 예방 하는 데 도움이 될 것으로 사료된다. 후속연구에서는 2,3 세의 어린 아동을 포함하는 다양한 연령대와 다른 장애군을 대상으로 말소 리장애 선별검사로서의 유용성에 대한 추가적인 연구 및 타당도 작업이 필요하며, 실제로 현장에서 사용하면서 발생될 수 있는 문 제를 예측하여 보완, 수정할 필요가 있겠다. 또한, 부모의 특성(예: 부모의 성향, 사회경제적 지위 등)이 아동의 말명료도 평정에 미치 는 영향에 대해서 살펴볼 필요가 있으며, 국내 상황에서 해당 선별 
Youngmee Lee - Speech Intelligibility of Children with SSD as Judged by Their Parents

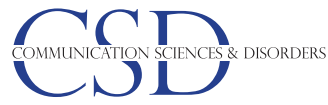

검사가 보급, 확대되기 위한 방안을 모색할 필요도 있겠다.

\section{REFERENCES}

Almost, D., \& Rosenbaum, P. (1998). Effectiveness of speech intervention for phonological disorders: a randomized controlled trial. Developmental Medicine and Child Neurology, 40, 319-325.

Baudonck, N., Buekers, R., Gillebert, S., \& Van Lierde, K. (2009). Speech intelligibility of Flemish children as judged by their parents. Folia Phoniatrica et Logopaedica, 61, 288-295.

Baudonck, N., Dhooge, I., \& Van Lierde, K. (2010). Intelligibility of hearing impaired children as judged by their parents: a comparison between children using cochlear implants and children using hearing aids. International Journal of Pediatric Otorhinolaryngology, 74, 1310-1315.

Bernthal, J., Bankson, N. W., \& Flipsen, P. (2013). Articulation and phonological disorders: speech sound disorders in children (2nd ed). Boston, MA: Pearson Education.

Broomfield, J., \& Dodd, B. (2004). Children with speech and language disability: caseload characteristics. International Journal of Language \& Communication Disorders, 39, 303-324.

Broomfield, J., \& Dodd, B. (2011). Is speech and language therapy effective for children with primary speech and language impairment? Report of a randomized control trial. International Journal of Language \& Communication Disorders, 46, 628-640.

Dale, P. S. (1991). The validity of a parent report measure of vocabulary and syntax at 24 months. Journal of Speech, Language, and Hearing Research, $34,565-571$.

Felsenfeld, S., Broen, P. A., \& McGue, M. (1994). A 28-year follow-up of adults with a history of moderate phonological disorder: educational and occupational results. Journal of Speech, Language, and Hearing Research, 37, 1341-1353.

Flipsen, P. (1995). Speaker-listener familiarity: parents as judges of delayed speech intelligibility. Journal of Communication Disorders, 28, 3-19.

Hustad, K. C., Schueler, B., Schultz, L., \& DuHadway, C. (2012). Intelligibility of 4-year-old children with and without cerebral palsy. Journal of Speech, Language, and Hearing Research, 55, 1177-1189.

Kim, J. H., Ballard, E., \& McCann, C. M. (2016). Parent-rated measures of bilingual children's speech accuracy: implications for a universal speech screen. International Journal of Speech-Language Pathology, 18, 202-211.

Kim, M. J., Pae, S., \& Park, C. I. (2007). Assessment of phonology for children
(APAC). Incheon: Human Brain Research \& Consulting Co.

Kim, M., \& Ha, S. (2012). Speech intelligibility development of children aged 24 to 48 months according to listener's familiarity with child's speech. Korean Journal of Communication \& Disorders, 17, 582-590.

Kim, S. J., \& Shin, J. Y. (2015). Speech sound disorders. Seoul: Sigma Press.

Kim, S. J., Kim, M. J., Ha, S., \& Ha, J. W. (2015). A survey of speech sound disorders in clinical settings. Communication Sciences \& Disorders, 20, 133144 .

Kim, S. J., Ko, Y. K., Seo, E. Y., \& Oh, G. A. (2017). Prevalence of speech sound disorders in 6-year-old children in Korea. Communication Sciences \& Disorders, 22, 309-317.

Kim, Y. T., Hong, G. H., Kim, K. H., Jang, H. S., \& Lee, J. Y. (2009). Receptive and expressive vocabulary test (REVT). Seoul: Seoul Community Rehabilitation Center.

Law, J., Boyle, J., Harris, F., Harkness, A., \& Nye, C. (2000). Prevalence and natural history of primary speech and language delay: findings from a systematic review of the literature. International Journal of Language and Communication Disorders, 35, 165-188.

McAllister, L., McCormack, J., McLeod, S., \& Harrison, L. J. (2011). Expectations and experiences of accessing and participating in services for childhood speech impairment. International Journal of Speech-Language Pathology, 13, 251-267.

McCormack, J., McLeod, S., McAllister, L., \& Harrison, L. J. (2009). A systematic review of the association between childhood speech impairment and participation across the lifespan. International Journal of Speech-Language Pathology, 11, 155-170.

McLeod, S. (2013). Speech sound acquisition. In J. E. Bernthal et al. (Eds.), Articulation and phonological disorders: speech sound disorders in children (2nd ed., pp. 58-113). Boston, MA: Pearson Education.

McLeod, S., Crowe, K., \& Shahaeian, A. (2015). Intelligibility in context scale: normative and validation data for English-speaking preschoolers. Language, Speech, and Hearing Services in Schools, 46, 266-276.

McLeod, S., Harrison, L. J., \& McCormack, J. (2012a). Intelligibility in context scale. Sydney: Charles Sturt University. Retrieved from http://www.csu. edu.au/_data/assets/pdf_file/0005/754466/ICS-Korean.pdf.

McLeod, S., Harrison, L. J., \& McCormack, J. (2012b). The intelligibility in context scale: validity and reliability of a subjective rating measure. Journal of Speech, Language, and Hearing Research, 55, 648-656.

McLeod, S., Harrison, L. J., McAllister, L., \& McCormack, J. (2013). Speech sound disorders in a community study of preschool children. American 
Journal of Speech-Language Pathology, 22, 503-522.

McLeod, S., Press, F., \& Phelan, C. (2010). The (in)visibility of children with communication impairment in Australian health, education, and disability legislation and policies. Asia Pacific Journal of Speech, Language and Hearing, 13, 67-75.

Ng, K. Y. M., To, C. K. S., \& McLeod, S. (2014). Validation of the intelligibility in context scale as a screening tool for preschoolers in Hong Kong. Clini- cal Linguistics \& Phonetics, 28, 316-328.

Overby, M., Carrell, T., \& Bernthal, J. (2007). Teachers' perceptions of students with speech sound disorders: a quantitative and qualitative analysis. Language, Speech, and Hearing Services in Schools, 38, 327-341.

Stertzbach, J. (2005). Parent report as a screening tool of speech disorders in Spanish-speaking preschool children (Master's thesis). Portland State University, Portland, OR, USA. 


\section{특정 대화자 말명료도 척도: 한국어}

Intelligibility in Context Scale (ICS): Korean

(McLeod, Harrison, \& McCormack, 2012)

번역 : Jae-Hyun Kim, MSLTPac, The University of Auckland, Auckland, New Zealand, 2013

이름:

생년월일:

성별 (남/여):

사용하는 언어:

검사일: 나이:

검사자 :

아동과의 관계:

다음 할목들은 다른 사람들이 당신의 아이의 발음을 얼마나 쉽게 이해하는지에 관한 질문입니다. 당신의 아이의 지난 한 달간의 발음을 생각하며 답을 하여 주십시요. 각 질문어 해당되는 한 번호을 선택하여 주십시요.

\begin{tabular}{|c|c|c|c|c|c|}
\hline & 함상 & 자주 & 가끔 & 드물게 & $\begin{array}{l}\text { 전혀 } \\
\text { 못함 }\end{array}$ \\
\hline 1. 당신은 당신의 아이를 이해합니까 ${ }^{1}$ ? & 5 & 4 & 3 & 2 & 1 \\
\hline 2. 직계 가쪽들은 당신의 아이를 이해합니까? & 5 & 4 & 3 & 2 & 1 \\
\hline 3. 다른 가족들은 당신의 아이를 이해합니까? & 5 & 4 & 3 & 2 & 1 \\
\hline 4. 아이의 친구들은 당신의 아이를 이해합니까? & 5 & 4 & 3 & 2 & 1 \\
\hline 5. 당신이 아는 다른 사람들은 당신의 아이를 이해합니까? & 5 & 4 & 3 & 2 & 1 \\
\hline 6. 아이의 선생님들은 당신의 아이를 이해합니까? & 5 & 4 & 3 & 2 & 1 \\
\hline $\begin{array}{l}\text { 7. 당신의 아이를 모르는 사람들은당신의 아이를 } \\
\text { 이해합니까? }{ }^{2}\end{array}$ & 5 & 4 & 3 & 2 & 1 \\
\hline 총점= & $/ 35$ & & & & \\
\hline 평균점= & $/ 5$ & & & & \\
\hline
\end{tabular}

${ }^{1}$ '아이'를 '배우자'르 대체하여 성인 박욤 펌가 척도로 사용하실 수 있슨니다.

'므르는 사랄들'은 '익숙하지 얋은 사랕들'로

이 특정 대화자 말명료도 척도는 복사하여 사용이 가능합니다. (This version of the Intelligibility in Context Scale can be copied.) Intelligibility in Context Scale is licensed under a Creative Commons Attribution-Noncommercial-NoDerivs 3.0 Unported License.

MeLeod, 5., Harrison, L. J., \& Mccormack, J. (2012). The Intelligibility in Context 5cale: validity and reliability of a subjective rating measure. Journal of Speech, Language, and Hearing feseorch, 55(2), 648-656. http://is/hr. asha.org/cci/content/abstract/55/2/648 


\section{국문초록}

\section{말소리장애 아동 선별을 위한 말명료도 부모 평정의 효용성 탐색}

이영미

동명대학교 언어치료학과

배경 및 목적: 본 연구에서는 부모 평정 말명료도 점수와 표준화된 발음평가의 자음정확도 간에 유의한 상관이 있는지를 살펴보고, 부 모 평정 말명료도 척도가 말소리장애 아동과 일반 아동을 선별하는 데 유용한 도구가 될 수 있는지를 알아보고자 하였다. 방법: 생활연 령이 만 4-6세의 일반 아동 55명과 말소리장애 아동 23명의 부모를 대상으로 말명료도 척도를 이용하여 자녀의 말명료도를 평정하게 하였으며, 대상 아동에게는 표준화된 아동용 발음평가(APAC)를 실시하여 자음정확도를 산출하였다. 결과: 상관분석 결과, 두 집단 모 두에서 부모 평정 말명료도 점수와 자음정확도 간에 유의한 상관을 보였다. 로지스틱 회귀분석 결과, 부모가 평정한 말명료도 점수는 일반 아동과 말소리장애 아동을 분류하는 데 유의한 변수로 나타났다. 논의 및 결론: 본 연구를 통해 부모가 평정하는 말명료도 척도 가 말소리장애 아동을 조기에 선별하는 데 유용한 도구로 활용될 수 있다는 것을 확인하였다.

핵심어: 말소리장애, 아동, 말명료도, 부모, 선별

\section{참고문헌}

김미진, 하승희(2012). 청자의 친숙도에 따라 낱말수준에서 살펴본 24-48개월 아동의 말 명료도 발달 연구. 언어청각장애연구, 17, 582-590.

김민정, 배소영, 박창일(2007). 아동용발음평가(APAC). 인천: 휴브알앤씨.

김수진, 고유경, 서은영, 오경아(2017). 우리나라 6세 아동의 말소리장애 출현율. 언어청각장애연구, 22, 309-317.

김수진, 김민정, 하승희, 하지완(2015). 임상현장의 말소리장애 현황. 언어청각장애연구, 20, 133-144.

김수진, 신지영(2015). 말소리장애. 서울: 시그마프레스.

김영태, 홍경훈, 김경희, 장혜성, 이주연(2009). 수용·표현어휘력검사(REVT). 서울: 서울장애인종합복지관. 